Our Nature
Journal homepage: http://nepjol.info/index.php/ON

\title{
Conflict due to Assamese Macaques (Macaca assamensis McClelland 1840) and crop protection strategies in Kali- gandaki River Basin, Western Nepal
}

\author{
Pavan Kumar Paudel \\ Central Department of Zoology, Tribhuvan University, Kirtipur, Kathmandu, Nepal \\ ${ }^{*}$ E-mail: pavanreturn@gmail.com
}

\begin{abstract}
This study was conducted on conflict due to Assamese Macaques (Macaca assamensis McClelland 1840) and crop protection strategies in Kaligandaki river basin, Baglung and Parbat Districts, Western Nepal_.Field survey was conducted from 25 October to 22 December, 2015. Questionnaire survey was carried out to estimate the crop protection strategies and crop damaged by the macaque with the local inhabitants in the Kaligandaki River Basin VDCs. Stratified random sampling method was used to select respondent for the questionnaire survey. Out of 654 river basin households, 92 respondents were selected as sample size from the study area. Maize was the highest raided crop $46.95 \%$ followed by $15.91 \%$ paddy, $15.11 \%$ potato, $10.84 \%$ millet, $6.88 \%$ wheat, $2.05 \%$ pulses, $1.59 \%$ fruits and $0.66 \%$ vegetables. The most commenly used crop protection strategy in guarding their field were by constant vigilance $50 \%, 25 \%$ of field owners use "Scarecrows" $20 \%$ used dogs, $5 \%$ farmers used tin-box and catapult to chase the macaques from the crop fields.
\end{abstract}

Key words: Assamese Monkey, Crop damage, Western Nepal, Questionnaire

DOI: http://dx.doi.org/10.3126/on.v14i1.16449

Manuscript details: 26.11.2016 / Accepted: 26.12.2016

Citation: Paudel, P.K. 2016. Conflict due to Assamese Macaques (Macaca assamensis McClelland 1840) and crop protection strategies in Kaligandaki River Basin, western Nepal. Our Nature 14(1):107-114. DOI: http://dx.doi.org/10.3126/on. v14i1.16449

Copyright: ( Paudel 2016. Creative Commons Attribution-NonCommercial 4.0 International License.

\section{Introduction}

In Nepal there are two species of macaques; Macaca assamensis and Macaca mulatta, and one species of Langur; Semnopithecus entellus, with subspecies distributed from the Tarai plain to the high mountain range (Chalise, 1995). The Rhesus monkeys (Macaca mulatta Zimmermann, 1780) are 
found freely ranging in wild as well as in urban religious places. The Langur monkeys (Semnopithecus entellus Dufresne 1797) are found freely ranging in wild forest and marginal areas of Nepal (Southwick et al., 1982). The other species Assamese monkey (Macaca assamensis McClelland 1840) reported from mid-hills and high Montana forest of Nepal, whose ecological and behavioral details are still largely unknown (Chalise, 2006).

The Assamese Macaques is categorized as threatened due to its limited distribution of less than $22,000 \mathrm{~km}^{2}$, an expected area of occurrence of about $914 \mathrm{~km}^{2}$ with ongoing decline in area, lessening population and narrowing quality of habitat. As stated of its restriction of occurrence, rising threats to the individual and its habitat, and decreasing number in fragmented patches, the Nepal Assamese population is categorized as Endangered. As well as the National parks and wild life conservation Act of 1973 has listed the Assamese Macaque as a protected species of Nepal and kept appendix II of CITES (Chalise et al., 2005). Because of their distribution pattern, Assamese Macaque population would have been more influenced by forest habitat deterioration compared with Rhesus Macaque populations (Wada, 2005). The fragmented distribution of the Assamese Macaque seems inadequate for maintaining a viable population in Nepal. There has been few studies to estimate the minimal viable population size necessary for the conservation of not only Assamese Macaques, but macaca in general (Wada, 2005). Species viability can be measured by evaluating population dynamics and environmental effects ( $\mathrm{Fa}$ and Lind, 1996).

In Nepal, crop damage is very common along the mid-hills, high mountain area, Terai and immediate periphery of national parks and reserves. Primates are considered to the pest of field crops Langurs in Sworgadwari forest of Pyuthan, Sangekhola of Tanahun, Assamese Macaques of Hariharpur Gadhi, Rhesus Macaques in Ghodaghodi of Kailali and Pashupati, Swoyambhu, Thapathali and Sankhu of Kathmandu, and elsewhere (Chalise, 2000). Rhesus Monkey was considered most crops damaging, while physical hurt and harassment were also perceived monkey related problem in the Gulmi area. Shouting and chasing with using stone and catapult were the common local deterrent method against monkeys (Aryal and Chalise, 2013). However, Upreti (1990) noted that buckwheat and barley were repeatedly destroyed by wild pigs, langurs, and macaque monkeys in Langtang and Rara national parks. Little quantitative information on crop loss or damage is available for this study area on the edge between continuous forest and dense human habitation zones along the southern boundary of the national park area (Jackson, 1990).

\section{Materials and methods \\ Research site}

The study was conducted in Baglung and Parbat districts of Dhawalagiri Zone. It lies in the western development region of Nepal. The district Baglung is a part of Province No. 6, with its district headquarters baglung, cover an area of $1,784 \mathrm{~km}^{2}$ and have a population (2001) of 268,938. Parbat district is a hilly area of Nepal. The district Parbat is a part of Province no 4 and one of the seventy-five district of Nepal. The district, with Kusma as its district headquarters, covers an area of $494 \mathrm{~km}^{2}$ and has a population (2001) of 157,826 . Study site is located between $83^{\circ} 35^{\prime} 29.2^{\prime \prime}$ to $83^{\circ} 35^{\prime} 72^{\prime \prime}$ 
longitude and $28^{\circ} 05^{\prime} 24.2^{\prime \prime}$ to $28^{\circ} 19^{\prime} 45^{\prime \prime}$ latitude and elevation ranges between $560 \mathrm{~m}$ to $1650 \mathrm{~m}$.

Total area of Baglung site VDCs is $71.3452 \mathrm{~km}^{2}$ where as Parbat site VDCs is $33.357 \mathrm{~km}^{2}$. The study area lies in between tropical to temperate belt of Nepal. This study area has a unique geographical feature having both North and South facing topography. The rain-bearing wind from the Bay of Bengal blows from the east towards west of Nepal during the rainy season. The climate of study area and its vicinity is mainly dry and wet (Source: NG/ RDHM Pokhara). The average maximum temperature was recorded $\left(27.70^{\circ} \mathrm{C}\right)$ and minimum temperature was recorded $\left(15.30^{\circ} \mathrm{C}\right)$ (Source: NG/RDHM Pokhara). According to the climatic data, average monthly relative humidity (at morning) of the area $77.17 \%$ and average monthly relative humidity (at evening) of the area $78.15 \%$. The highest precipitation was recorded (553.6 $\mathrm{mm}$ ) in the month of July during the study period, while there were not recorded of precipitation in the month of November and December (Source: NG/ RDHM Pokhara). The study area is rich in biodiversity. The reason for this may be due to presence of alluvial soil along the basin of this large Kaligandaki River, and high productivity of tropical deciduous riverine forest (Chalise, 2013). In broad classification, the study area falls in Shorea-Diospyros zone (Paudel, 2016). Mixed type of forest is found in the study area. Tropical deciduous riverine forest sub-tropical grassland and subtropical evergreen forest are the forest types in the study area (Chalise, 2013).

\section{Methods}

Study area was divided into four blocks namely Block A (Chisti, Jaidi, Arjewa and
Binamare VDCs), Block B (Kusmisera, Amalachaur and NarayansthanVDCs), Block C (Siwalaya and Pang VDCs) and Block D (Nangliwang and Dhairing VDCs). Blocks were designed on the basis of habitat character (Rijal, 2014). Which were separated by large Kaligandaki river i.e., Block A and B from Baglung District site where as Block C and D from Parbat District site.

\section{Questionnaire survey}

Stratified random sampling method was used to select respondent for the questionnaire survey. The main habitats of the Assamese Monkey were along the Kaligandaki River Basin therefore, out of 654 river basin households, 92 respondents were selected as sample size from the study area. To estimate the crop protection strategies and crop damaged by the Assamese Macaque in the study area questionnaire survey was conducted from 25 October to 22 December, 2015 to collect information with the local inhabitants in the Kaligandaki River Basin VDCs.

\section{Results}

\section{Crop raiding}

In the study site crop raiding was found to be the major problem caused by the monkey. Among the respondents crop raiding was reported by $80 \%$ but the extent of crop raiding was found to be different areas. Crop raiding was found to be highest at Block A Aduwabari village of Chhisti VDC Baglung (78\%) followed by the Block D Dhairing, at the edge of Salyan village with rocky out crop of Dhairing VDC Parbat least to the crop raiding (61\%). Major crops raided by monkeys included maize, potato, millet, wheat, paddy, pulses, vegetables, (pumpkin, bean, cauliflower, 
cabbage etc.), and fruits (pear, peach, cucumber, etc.). In which maize was the highest raided crop. From the total 92 respondents, total loss noted was $46.95 \%$ of maize, followed by $15.91 \%$ paddy, $15.11 \%$ potato, $10.84 \%$ millet, $6.88 \%$ wheat, $2.05 \%$ pulses, $1.59 \%$ fruits and $0.66 \%$ vegetables (Fig. 1). Most of the respondents had very limited crop land to grow their crops. Out of this respondents, $50 \%$ respondents were facing more trouble from the crop raiding problems and 5\% respondents had already left some land fallow due to severe crop raiding problem.

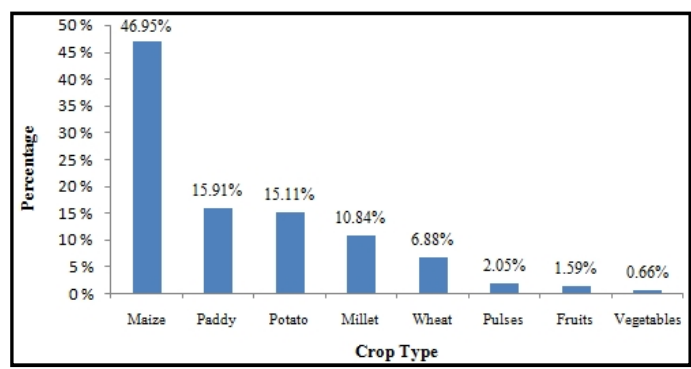

Figure 1. Crop damage (\%) by Assamese Macaques in the Kaliganaki River Basin Baglung and Parbat districts Nepal, 2016.

Out of the total 92 respondents, a total of 61.18 hectare of land was utilized for the cultivation of crops. In that land area, total yield of crop was expected to be 688.29 quintals but 567.74 quintals was observed yield during the study time. It is indicaded that 120.55 quintals of crops was lost by the Macaques, on the basis of average monetary value was accumulated from Baglung Bazar (Tab. 1). Among the various raided crops, maize was found highly raided that worth the loss Rs. 226400. All together, the loss of raided crops worth Rs. 558926 from questionnaire surveyed area the result showed that 14.98 quintals of crops was raided in each hectare of land (Tab. 2).

Table 1. Local market price of crops at Baglung Bazar.

\begin{tabular}{ccc}
\hline S.N. & Crops & NRs/Quintal \\
\hline 1 & Maize & 4000 \\
2 & Potato & 5000 \\
3 & Millet & 3800 \\
4 & Wheat & 3500 \\
5 & Paddy & 6500 \\
6 & Fruits & 4500 \\
7 & Pulses & 10000 \\
8 & Vegetables & 6000 \\
\hline
\end{tabular}

\section{Crop protection strategies}

To protect crop fields and orchards from wildlife including Assamese Macaque, farmers used many methods. These methods include patrolling and guarding the fields by farmers including their children, Scarecrow, Tin-box, throwing stone with "Catapult", keeping Dogs, fencing with thorny twigs etc. The most commonly used crop protection strategy in guarding their field by constant vigilance during croop seasons. This method was used by $50 \%$ of the farmers in the study area. $25 \%$ of field owners use "Scarecrows"(a device to scare the animals from the field). Few farmers about 20\% used dogs for crop protection to chase the macaques away, while the remaining 5\% farmers used tin-box and catapult (a device made with rubber to hit the distant objects) to chase the macaques from the crop fields (Fig. 2).

Along with above methods all the farmers commonly fence their farms using thorny twigs and branches of different trees and shrubs as protective measures. Despite all these measures of crop protection, macaques do manage to invade the crops. 
Table 2. Crop raiding rate of Assamese Macaque in study area.

\begin{tabular}{|c|c|c|c|c|c|c|}
\hline \multirow{2}{*}{ Crops } & \multirow{2}{*}{ Total land (ha) } & \multicolumn{2}{|c|}{ yield (Quintal) } & \multicolumn{3}{|c|}{ Loss } \\
\hline & & Expected & Observed & Quintal & NRs & Quintal/ha \\
\hline Maize & 15.19 & 118.12 & 61.52 & 56.6 & 226400 & 3.72 \\
\hline Paddy & 18.54 & 312.51 & 293.33 & 19.18 & 124670 & 1.03 \\
\hline Wheat & 12.71 & 104.76 & 96.46 & 8.3 & 29050 & 0.65 \\
\hline Millet & 4.13 & 64.81 & 51.74 & 13.07 & 49666 & 3.16 \\
\hline Potato & 5.56 & 43.63 & 25.41 & 18.22 & 91100 & 3.27 \\
\hline Pulses & 2.51 & 13.32 & 10.87 & 2.46 & 24600 & 0.98 \\
\hline Fruits & 1.23 & 19.43 & 17.51 & 1.92 & 8640 & 1.56 \\
\hline Vegetables & 1.31 & 11.71 & 10.91 & 0.8 & 4800 & 0.61 \\
\hline Total & 61.18 & 688.29 & 567.74 & 120.55 & 558926 & 14.98 \\
\hline
\end{tabular}

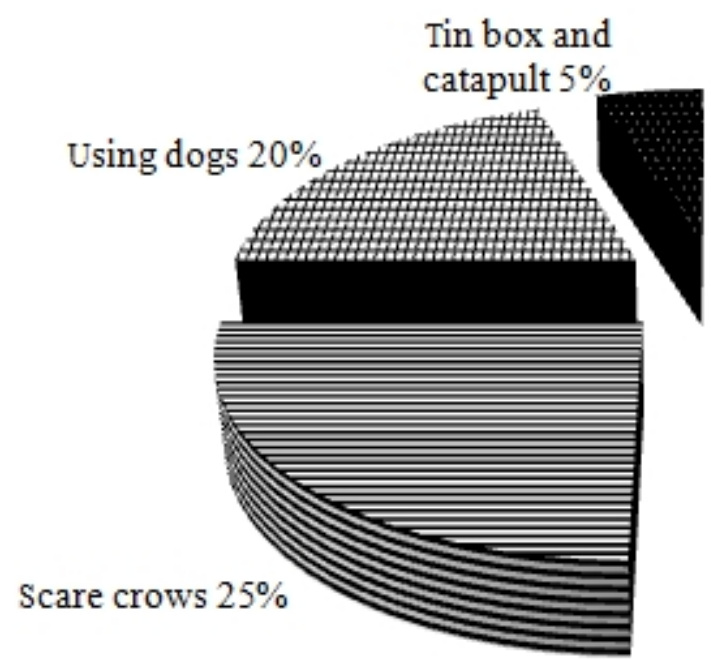

Vuarding the field = Scaresrows

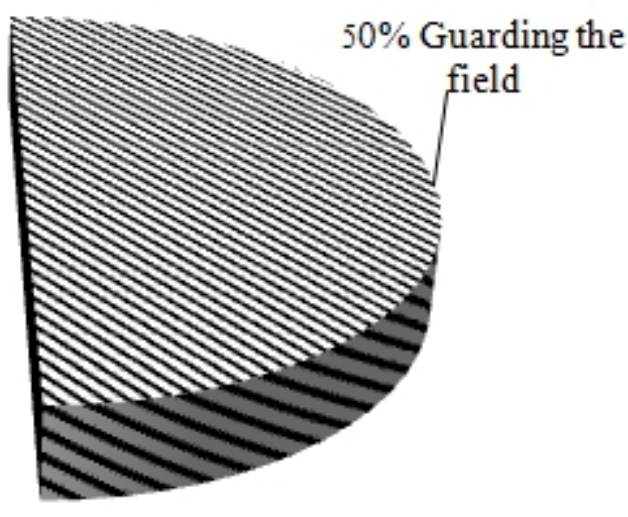

\# Using dogs Tin box and catapult

Figure 2. Different crop protection strategies used by farmers in the Kaliganaki River Basin, Baglung and Parbat districts Nepal, 2016. 


\section{Discussion}

Crop raiding was found as a major cause of conflict though physical hurt and harassment, taking and grabbing of food materials were also reported as the problems caused by monkeys. Among the respondents crop raiding was reported by $80 \%$ but the extent of crop raiding was found to be different areas. Crop raiding was found to be highest at Block A, Aduwabari village of Chhisti VDC, Baglung (78\%) followed by the Block D, Dhairing, at the edge of Salyan village with rocky out crop of Dhairing VDC Parbat least to the crop raiding (61\%). Higher extent of crop raiding in former two is due to the settlement and crop field very near to the forest. Khatri (2006) found that $76 \%$ of respondents of Vijayapur Area of Dharan reported the crop raiding as a major problem. Similar in the study of McCourt (2005), 92\% respondents of Hetauda were found to suffer from crop damage from monkeys, Adhikari (2013) 78\% of respondents of Lamjung area reported crop raiding as a major problem. Chalise (2000) collected the information of crop raiding by the interviews in Lakuwa village of MBCA and reported that Rhesus and Assamese Macaques were the most crop raiders and langurs visited the least and the villagers blamed that among the two species, Assamese Monkey was the terrible than rhesus. This study couldn't be similar with this present study where the villagers blamed that among the two species, Rhesus Monkey were the terrible than the Assamese, and he stated that monkey raid heavily to the maize field $29 \%$ then followed potatoes $23 \%$ (tubers also), rice $13 \%$, fruits $12 \%$, and millets $12 \%$. The tubers and fruits came to be $35 \%$ of the total loss and the total cereals came to be $65 \%$ loss in Lakuwa village but here this crop raiding ratio of fruit and cereals crop was similar to this present study. Regmi (2008) reported crop raiding in LNP by $62 \%$ for maize, $23 \%$ for potato, $7 \%$ for millet, $6 \%$ for buckwheat and $2 \%$ for other, which result is similar to the finding of the present study. Khatri (2006) also supports that maize is the prominently vulnerable crops for raiding by primates. Adhikari (2013) found crop raiding by Assamese Monkey in Lamjung area, 44\% maize followed by $27 \%$ potato, $13 \%$ millet, $7 \%$ wheat, $4 \%$ paddy, $3 \%$ fruits and $2 \%$ vegetables this finding also supports the present study might be due to the similar type of geology in between these two study sites.

Different preventive measures were applied to deter monkey, though chasing of monkey by shouting and guarding was found to be most effective and widely used measure. Local people usually protect their crop and chased monkey by shouting and guarding. Small hut locally called "Chhapro" were made to guard the field. Use of dog use of catapult and stone to chase monkeys, hitting tin boxes as well as other method like planting alternative crops were also found. Khattri (2006) in Vijayapur found the use of catapult to frighten the monkeys to be the most effective which is similar with present study. Bagale (2003) found guarding overnights as an effective crop protection technique in Lumbini area in order to protect their crops from Nilgai (Boselaphus tragocamelus) a nocturnal crop raider. In this present study guarding field as most employed crop protection technique in this large river basin from Assamese Macaque, a diurnal crop raider. Though the guarding/chasing is the most effective method of deterrent in which mainly the woman and children engage, it is time expensive and keeps people away from other activities (Southwick and Siddi- 
qi, 1977; Bell, 1984; Southwick and Lindburg, 1986; King and lee, 1987; Pirta et al., 1997; Knight, 1999; Hill, 2000) especially consumes the time of educational activities of children in such remote areas which further move the poor people backward through long lasting impacts. So the loss is invaluable in comparison with time rather than economy. Chhangani and Mohnot (2004) in a study in and around Aravallis of India, Calculated the percentage of crop protection methods by farmers as $60 \%$ guarding fields, $20 \%$ throwing stones, $15 \%$ using dogs and $5 \%$ others including dangerous method like single shot gun, potash bomb and high voltage electric current in which animals are usually killed or seriously injured but the farmers of this study areas were not used cruel type of crop protection strategies but in this study Guarding the field $50 \%$, scare crows $25 \%$, Using dog $20 \%$, Tin box and Catapult $5 \%$ because like that of gun and potash bomb are prohibited by his majesties of government for the use to public. McCourt (2005) in Hetauda found stone throw catapult $40 \%$, followed by chasing $20 \%$, threaten $18 \%$ and stick wave $2 \%$. Adhikari (2013) reported that Guarding and shouting $68 \%$, stone and catapult $16 \%$ and hitting tin box and using dogs $12 \%$ from Lamjung Area but in this study Guarding the field $50 \%$, Scare crows $25 \%$, Using dog $20 \%$, Tin box and Catapult $5 \%$ the difference between $68 \%$ guarding and shouting and guarding $50 \%$ may be due to the children of this study area are engaged in school for their study.

\section{Acknowledgements}

I would like to acknowledge National Trust for Nature Conservation for providing research grant. I am thankful to Central Department of Zoology, Tribhuvan University for cooperation and Department of Forest, Babarmahal for providing permission to conduct the research in the study area. I am grateful to Dr. Mukesh Kumar Chalise for his kind supervision. I am thankful to $\mathrm{Mr}$. Shivish Bhandari for his kind help. Sincere thanks are extended to local people for providing information.

\section{References}

Adhikari, R.K. 2013. Population status, distribution and general behavior of Assamese Macaque (Macaca assamensis, McClelland, 1840) in Taghring and Ghermu VDCs, Lamjung, Nepal. Central Department of Zoology, Tribhuvan University, Nepal. (M.Sc. thesis)

Aryal, K. and M.K. Chalise 2013. Human-monkey interface in Arkhale and Nayagaun, Gulmi, West Nepal. Nepalese Journal of Zoology 1(1): 30-40

Bagale, I. 2003. Population status of Nilgai (Boselaphus tragocamelus) and livestock - people interaction: A case study in Lumbini. Central Department of Zoology, Tribhuvan University, Nepal. (M.Sc. thesis)

Bell, R.V.H. 1984. The man animal interface: An assessment of crop damage and wildlife control. In Conservation and Wildlife Management in Africa (R.H.V. Bell and McShane-Caluzi, E. eds.), US Peace Crops. pp. 387-416.

Chalise, M.K. 1995. Comparative study of feeding ecology and behavior of male and female langurs (Presbytis entellus). Central Department of Zoology, Tribhuvan University, Nepal. (Ph.D. thesis)

Chalise, M.K. 2000. Crop raiding by wildlife, specially primates and indigenous knowledge of food conservation. Asian Primates 7(3-4): 4-9.

Chalise, M.K. 2006. Primate census in different parts of Nepal. Journal of the University Campus TU$T A, T U$, Prospective on Higher Education. 2-3: 35-41.

Chalise, M.K. 2013. Biodiversity Conservation and Sustainable Management of Living Natural Resources Kaligandaki Upper Hydropower Project Nepal. A report submitted to Nepal consult, HES and NESS (P) Ltd.

Chalise, M.K., J.B. Karki and M.K. Ghimire 2005. Status in Nepal: Non-human Primate. In Special issue of $10^{\text {th }}$ Wildlife Week, DNPWC, Nepal. pp. 19-26.

Chhangani, A.K. and S.M. Mohnot 2004 Crop raid by Hanuman Langur (Simnopithecus entells) in 
and around Aravallis, India and its management. Primate Report 69: 35-47.

$\mathrm{Fa}$, J.E. and R. Linda 1996. Population management and viability of the Gibraltar Barbery Macaques. In Evolution and ecology of macaques societies (J.E. Fa and Lindburg, D.G. eds.), Cambridge University Press, London. pp. 235-262.

Hill, C.M. 2000. Conflict of interest between people and Boboons: Crop raiding in Uganda. Int. J. of Primatol. 21(2): 299-315.

Jackson, R. 1990. Threatened wildlife, crop and livestock depredation and grazing in the MakaluBarun Conservation Area. Makalu-Barun Conservation Project, DNPWC, HMG, Nepal. Report no. 12.

Khatri, P. 2006. Study on Monkey-Human conflict in Bijayapur area, Dharan, Eastern Nepal. Central Department of Zoology, Tribhuban Universiy, Nepal. (M.Sc. thesis)

King, F.A. and P.C. Lee 1987. A brief survey of Human attitudes to a pest species of Primate (Cercopithecus aethiops). Primate Conservation 8: 82-84.

Knight, J. 1999. Monkeys of move: The natural symbolism of People-Macaque conflict in Japan. The Journal of Asian Studies 58(3): 622-647.

McCourt, P. 2005. Urban Human-Monkey conflict in the vicinity of the Institute of Forestry, Hetauda, Nepal.

Paudel, P.K. 2016. Population status, distribution and general behavior of Assamese Monkey (Macaca assamensis McClelland, 1840) in Kaligandaki River Basin, Baglung and Parbat Districts,
Nepal. Central Department of Zoology, Tribhuvan University, Nepal. (M.Sc. thesis)

Pirta, R.S., M. Gagli and A.V. Kharshikar 1997. The management of Rhesus Monkey (Macaca mulata) and Hanuman Langur (Presbytis entellus) in Himanchal Pradesh, India. Biological Conservation 79: 97-106.

Regmi, G.R. 2008. Status of Assamese Macaque (Macaque assamensis, McCland 1840) in Langtang National Park. Central Department of Zoology, Tribhuvan University, Nepal. (M.Sc. thesis)

Southwick, C.H. and D.G. Lindburgh 1986. The primates of India, status trends and conservation. In Primates: The round to self-sustaining Population (K. Benirschke ed.), New York SpringerVerlag. pp. 171-187.

Southwick, C.H. and M.F. Siddiqi 1977. Population dynamics of Rhesus Monkey in Northern India. In Primate Conservation (P. Rainier III and Bourne, G.H. eds.), New York, Academic Press. pp. 339-362.

Southwick, C.H., J. Teas, T. Richie and H. Taylor 1982. Ecology and behavior of Rhesus monkey (Macaca mulata) in Nepal. National Geographic Society Report 14: 619-630.

Upreti, B.N. 1990. The Park-People interface in Nepal: Problems and new directions. In International Workshop on Management of National Parks and Protected Areas of Hindukush Himalayas, Kathmandu. pp. 19-24.

Wada, K. 2005. The distribution pattern of Rhesus and Assamese Monkeys in Nepal. Primates 46: 115-119. 